\title{
Ved kongens ligfærd igennem Flensborg
} 30. November 1863.

$D_{\text {isse vers, der blev skrevne af en deltager } i \text { kongens }}$ ligfærd, kom dengang ikke offenlig frem, fordi man antog deres historiske hentydninger til Sven Lstridsen og Margrete for uforstaielige. De meddeles nu som et samticligt vilnesbyrd om de stemninger og den opfattelse af forhold og personer, der dengang rådede blandt danske Sønderjyder. De oldre vil ved dem mâske kunne forny et tungt, men dyrebart minde, de yngre vil kunne fat et om end svagt indtryk af hin aftens store sorg og dens mange krydsende folelser og tanker.
A. D. Jørgensen.

Hil være dig, Frederik Folkekære, vi Sønderjyler til graven dig bære;

Som Skjold vi føre dit lig af land, du var os en frelsens konge for sand!

Hvor Sven sit trætte øje mon lukke, blandt os, du anded' de sidste sukke.

Som han ufortrøden i kamp du stod mod fjendens trodsende overmod. 
Ved kongens ligfærd igennem Flenshorg.

Nu hviler du på din sorte båre, al Danmark sig rejser med bitter tîre, som Vilhelm modtog sin herre Sven, sii modtager Danmark sin hjertensven;

som Vilhelm udinded' ved kong'ens bryst, vi fandt vel $i$ doden den dybeste trast.

Men som Sven sig avled' et heltekuld, si̊ stande vi kvær, når du lægges i muld,

en helteyngel med kongens mod, thi alle oprandt vi af kongeblod! Nu hviler du, Frederik Folkekære, nu dine sonner til graven dig bare!

Som Nordens dronning, den stolte Margrete, ved denne strand dit leje vi redte.

Som med Volmers datter er nu slukket ur en xldyammel stammes ædleste skud.

Den stolteste tanke, Norden fik skue, den tænkte hun først, den alvorlige frue, den djærveste (lid, *) vi danemænd sang, af kongens danske hjerte udsprang.

Nu mødes I snart i det tavse lejre, men tanken er vor og diiden skal sejre!

$\mathrm{Nu}$ samles I snart i de dørles stad, men evigt I lever i skjaldenes kvad!

*) Tilbagevisningen af de tyske fordringer, 24. Marts 1848. 
Ved kongens ligfærd igennem Flensborg.

Du lıvile i fred nu, du folkekære, de danske bolger til graven dig loære:

som Skjold vi forte dit lig af land, du var os en frolsens konge for sand! 